\title{
Size structure of planktonic particles in relation to hydrographic structure in the Skagerrak
}

\author{
Mati Kahru*, Aina Leeben \\ Institute of Ecology and Marine Research, Paldiski Rd. 1, Tallinn 200001, Estonia
}

\begin{abstract}
Horizontal distributions of the particle size spectrum and chlorophyll a concentration in near-surface water in relation to hydrographic structure were studied along a transect across the Skagerrak as part of the international SKAGEX-I exercise in May-June, 1990. Results are compared with those of Kiørboe et al. (Mar. Ecol. Prog. Ser. 59: 19-32, 1990) who explained changes in the plankton size structure and the food web as resulting from differences in water column stratification. It was confirmed that the particle size fraction corresponding to diatoms was most abundant along the Skagerrak periphery where stronger vertical mixing is assumed to take place. The smallest ( 1 to $4 \mu \mathrm{m})$, chlorophyll-correlated particulate fraction was most abundant in the central Skagerrak with the domelike near-surface stratification and the presumably reduced vertical mixing. However, distributions along the transect changed considerably over 1 to $3 \mathrm{~d}$ due to advection. In addition to the basin-wide changes, correlations of the different particle size fractions to chlorophyll concentration changed over much shorter length scales, often being in opposite phase to each other An equivalent spherical diameter of $4 \mu \mathrm{m}$ was the size at which the most significant shift in the horizontal distributions occurred.
\end{abstract}

\section{INTRODUCTION}

The fate of phytoplankton production in the ocean depends strongly on the dominant size of the primary producers. According to an emerging concept (e.g. Malone 1980, Kiørboe et al. 1990, Legendre 1990), stratified, oligotrophic environments are dominated by small-sized phytoplankton and the 'microbial loop' (Azam et al. 1983) type of food web, whereas in turbulent, well-mixed environments larger phytoplankton and the 'classical' type of food chain (phytoplanktonzooplankton-fish) dominate. Legendre \& Le Fevre (1989, 1990) use combinations of phytoplankton production and standing stock - whether dominated by large or small cells or resulting from a combination of various cell sizes - to construct a typology of pelagic marine ecosystems. These authors argue that the production of small versus large cells is primarily under hydrodynamic control, while the size-distribution of the standing stock in addition to phytoplankton production, is influenced by ecosystem structure. The typology based on phytoplankton cell size is relevant for the

\footnotetext{
- Present address: Swedish Meteorological and Hydrological Institute, S-60176 Norrköping, Sweden
}

export and sequestration of biogenic carbon, and for the exploitation of renewable marine resources. Such variations in the structure of the pelagic food web are observed on seasonal and ocean-wide scales (e.g. Cushing 1989) as well as on much smaller time and space scales (references in Kiørboe et al. 1990, Legendre 1990).

The surface waters in the Skagerrak are characterized by the general cyclonic circulation and a domeshaped pycnocline in its central gyre (Svansson 1975, Pingree et al. 1982). The strongly stratified central part is bounded by the Jutland Current in the south and the Norwegian Coastal Current in the north (Fig. 1). Both marginal currents have weaker or deeper stratification near the surface and presumably stronger vertical mixing.

In a study of the pelagic food web in the Skagerrak, Kiørboe et al. (1990) presented evidence of the dominance of the 'microbial loop' type of food web in the central 'dome' area and the shorter, 'classical' type of food chain along the margins. The authors explained this as a result of suppressed vertical mixing in the more stratified central waters as compared to the less stratified margins. However, their paper describes only a single transect on 18 to 21 May 1987. The same transect across the Skagerrak between Denmark and 


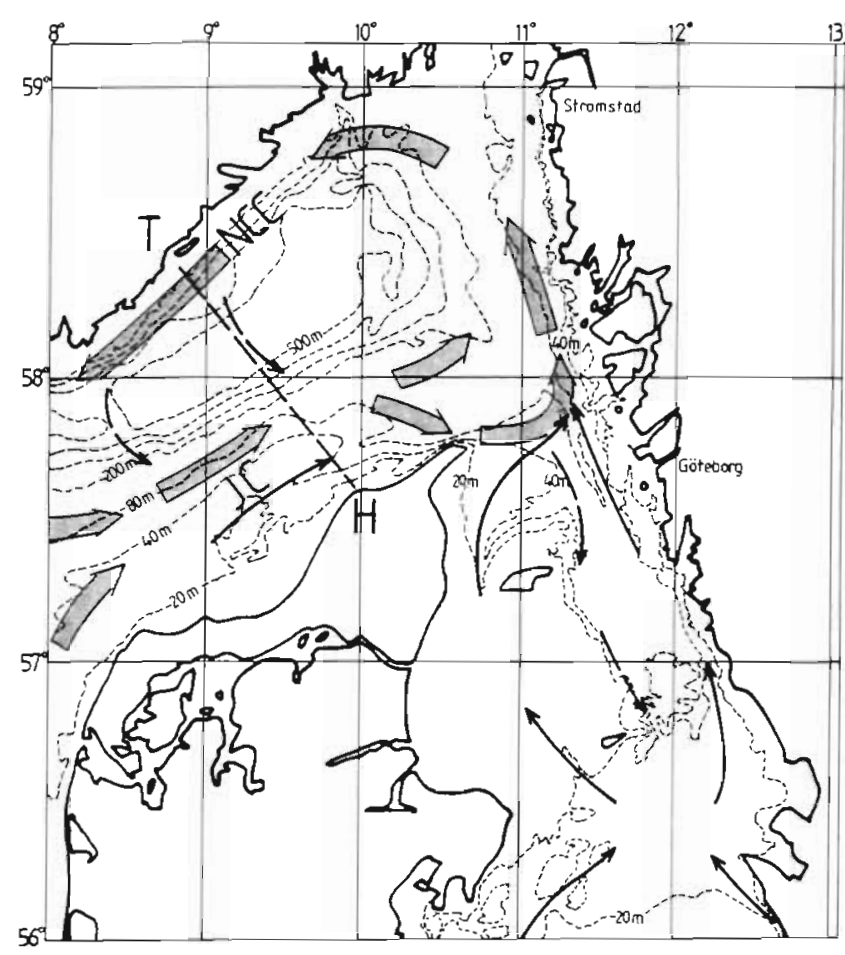

Fig. 1. The Skagerrak (modified from Svansson 1975) showing the Jutland Current (JC), the Norwegian Coastal Current (NCC) and the transect between Denmark (Hirtshals, H) and Norway (Torungen, T)

Norway was studied from RV 'Arnold Veimer' as part of the international SKAGEX-I exercise in May-June, 1990. Here we describe the results of continuous, underway particle and fluorescence measurements obtained on 5 traverses along the same line during a $2 \mathrm{wk}$ period. Our previous experience (Kahru \& Nômmann 1990. Kahru et al. 1991) shows that high-resolution, on-track measurements often provide insight unobtainable by conventional measurements on stations.

\section{MATERIALS AND METHODS}

Measurements. Near-surface particle concentrations, chlorophyll a fluorescence, temperature and salinity were measured when the ship was steaming back along the line between Torungen (Norway) and Hirtshals (Denmark) to resume measurements on the 'official' SKAGEX stations (Fig. 1). Altogether 5 crossings were completed (Table 1). The seawater intake for particle and fluorescence measurements was at about $5 \mathrm{~m}$ depth and the sampling interval was set at $1 \mathrm{~min}$. Water temperature and salinity were recorded by the ship's thermosalinograph. Depending on the speed of the ship the spatial interval was ca $250 \mathrm{~m}$. A HiacRoyco PC-320 particle size analyzer (Pugh 1978, Kahru \& Nômmann 1990) with 2 sensors (CMH-60 and E$1000)$ registered particles with equivalent spherical
Table 1. Date in 1990, time (GMT), and direction of the transects between Hirtshals, Denmark $(H)$ und Torungen, Norway (T)

\begin{tabular}{|rrrrl|}
\multicolumn{2}{c}{ Start } & \multicolumn{2}{c}{ End } & Direction \\
Date & Time (h) & Date & Time (h) & \\
& & & & \\
25 May & $18: 57$ & 26 May & $4: 08$ & $\mathrm{H} \rightarrow \mathrm{T}$ \\
26 May & $9: 02$ & 26 May & $17: 55$ & $\mathrm{H} \leftarrow \mathrm{T}$ \\
31 May & $20: 54$ & 1 June & $4: 39$ & $\mathrm{H} \rightarrow \mathrm{T}$ \\
3 June & $9: 12$ & 3 June & $16: 50$ & $\mathrm{H} \leftarrow \mathrm{T}$ \\
8 June & $18: 58$ & 9 June & $1: 45$ & $\mathrm{H} \leftarrow \mathrm{T}$ \\
\hline
\end{tabular}

diameters from 1 to $1000 \mu \mathrm{m}$ in 12 channels (Table 2). The sensors operate on the principle of light blockage. The counting time was $10 \mathrm{~s}$, during which $1 \mathrm{~cm}^{3}$ and $170 \mathrm{~cm}^{3}$ of seawater respectively passed through the 2 sensors. Counts in the top channel of the each sensor (i.e. Channels 6 and 12) were unreliable due to the relatively small number of particles per volume sampled.

In vivo fluorescence of the chlorophyll pigments was measured with a Turner Designs 10-005R fluorometer and calibrated against samples of extracted chlorophyll a obtained from the stations when the line was sampled in the reverse direction. Due to the considerable time difference (ca $24 \mathrm{~h}$ ) between these measurements, and the inherent sampling error, the regression cannot be expected to be perfect but is still highly significant ( $r=$ $0.73, \mathrm{n}=45, \mathrm{p}<0.001$ ). The salinity data from the thermosalinograph were also calibrated by using CTD casts on stations and can, therefore, only be regarded as an approximation (standard error of estimate $0.31 \%$ ).

Data analysis. The usual way of representing particle data is to express them as volume concentrations (Sheldon et al. 1972), but as particles can seldom be considered spherical, conversion of the projection area measured by the Hiac-Royco sensors to volume was not pursued. Moreover, the activity of organisms is roughly proportional to the surface area and not to the volume

Table 2. Particle size classes measured with the Hiac-Royco particle counter PC-320

\begin{tabular}{|ccc|}
\hline Sensor & Channel & Size range $(\mathrm{um})$ \\
\hline $\mathrm{CMH}-60$ & 1 & $1-2$ \\
& 2 & $2-4$ \\
& 3 & $4-6$ \\
& $6-10$ \\
$5-1000$ & 5 & $10-20$ \\
6 & $20-60$ \\
7 & $28-42$ \\
& 7 & $42-73$ \\
9 & $73-105$ \\
& 10 & $105-163$ \\
11 & $163-305$ \\
12 & $305-1000$ \\
\hline
\end{tabular}


(Fenchel 1974, Platt \& Denman 1978, Kirrboe et al. 1990). Hence, as a measure of the relative importance of a size fraction, the percent contribution of the size fraction to the estimated total particulate surface area (in the 1 to $1000 \mu \mathrm{m}$ range) is used.

To reduce random noise, the on-track data were usually averaged over 2 adjacent points making the final resolution on the plots ca $500 \mathrm{~m}$.

A characteristic feature of the various horizontal distributions is the changing of the sign and strength of the correlations between different measurement series over space, i.e. subsections of positive correlation tend to alternate with subsections of negative correlation. To delineate subsections with consistent relations between series, 'running' correlation coefficients were calculated between 2 series over shorter, overlapping subsections of 30 sample pairs equivalent to a distance of ca $15 \mathrm{~km}$. The calculated 'running' correlation coefficient ( $\mathrm{r}$ ) is analogous to the moving average. The levels of significance for $r$ are $\pm 0.36(p<0.05)$ and $\pm 0.48(p<0.01)$. However, as partly overlapping data points are used to compute adjacent correlations, the spatial separation between the points has to be at least 30 samples (ca $15 \mathrm{~km}$ for the averaged, ca $7.5 \mathrm{~km}$ for original series) for the estimates to be independent.

\section{RESULTS}

A typical near-surface salinity distribution (Fig. 2) showed the well-known features of higher salinity on the southern side (the Jutland Current), a drop-off towards the north, and a slight increase near the Norwegian coast. The salinity distribution on all the transects was qualitatively similar but quantitatively quite variable. Abrupt changes occurred between consecutive transects. Most notable was the northward spreading of the high-salinity area and the increasing salinity over most of the transect that occurred within only 5 to $10 \mathrm{~h}$ on 25 to 26 May (Fig. 3). These abrupt advective changes in a conservative variable during an interval shorter than the usual time interval between transects show the difficulties in trying to infer in situ biological dynamics in individual water masses. We shall therefore treat the transects rather as a set of random samples than as a sequence of contiguous stages in temporal development.

As expected, chlorophyll distributions were also variable (Fig. 3) with a tendency to higher values in both coastal currents.

On most of the transects (25 May, 31 May, 3 June), particle distributions had a characteristic pattern (Fig. 4 , top) of maxima in the smallest size fractions (1-2 and $2-4 \mu \mathrm{m}$ ) in the central gyre area, and maxima of all the $>4 \mu \mathrm{m}$ size fractions in the near-coast currents. The particle size where the shift to the opposite distribution pattern occurred was $4 \mu \mathrm{m}$ equivalent spherical diameter. However, 2 of the 5 transects did not conform with this pattern. On 26 May (Fig. 4, bottom), after a strong advectional change in salinity, the distributions of the $<10 \mu \mathrm{m}$ particles had become quite uniform while the $>10 \mu \mathrm{m}$ particles retained their maxima in the 2 coastal current areas (not shown). On 8 June all the size fractions, including the 1-4 $\mu \mathrm{m}$ fraction, had maxima on the periphery.

The contrasting distribution patterns of the different particle size fractions are best shown by their changing percent contributions to the total particulate surface areas (Fig. 5). In the central gyre up to $23 \%$ of the particulate surface area (in the 1 to $1000 \mu \mathrm{m}$ range) was made up solely by the 1-4 $\mu \mathrm{m}$ size fraction while in the Jutland Current the share of this fraction dropped below $3 \%$. The contributions of the larger particles showed opposite trends. This pattern was observed even on 26 May, when the absolute concentrations in the $<10 \mu \mathrm{m}$ range were quite homogeneous. Only on 8 June were the percent contributions uniform over the whole transect.

The $28-42 \mu \mathrm{m}$ and $42-73 \mu \mathrm{m}$ size fractions, generally corresponding to diatoms, increased drastically in the low-salinity plumes in the Norwegian Coastal Current, observed only on 25 and 26 May (Fig. 6). The lowsalinity plumes probably originated from the Oslo fjord. The increase in the plumes was 4 to 5 -fold (from 30 to $150 \mathrm{ml}^{-1}$ ) for the $28-42 \mu \mathrm{m}$ fraction. The plumes of 25 and 26 May differed between each other with respect to the 10-20 $\mu \mathrm{m}$ fraction, which showed a 3-fold increase on 26 May compared to no change on 25 May.
Fig. 2. Distributions of salinity (\%o; heavy continuous line), temperature $\left({ }^{\circ} \mathrm{C}\right.$; continuous line), and chlorophyll a ( $\mu \mathrm{g} \mathrm{I}^{-1}$, dotted) across the Skagerrak on 25 May 1990

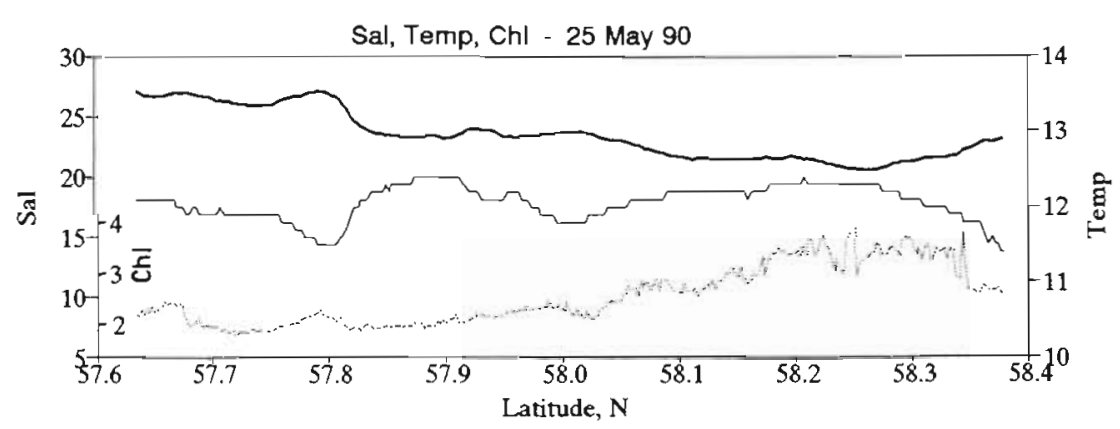



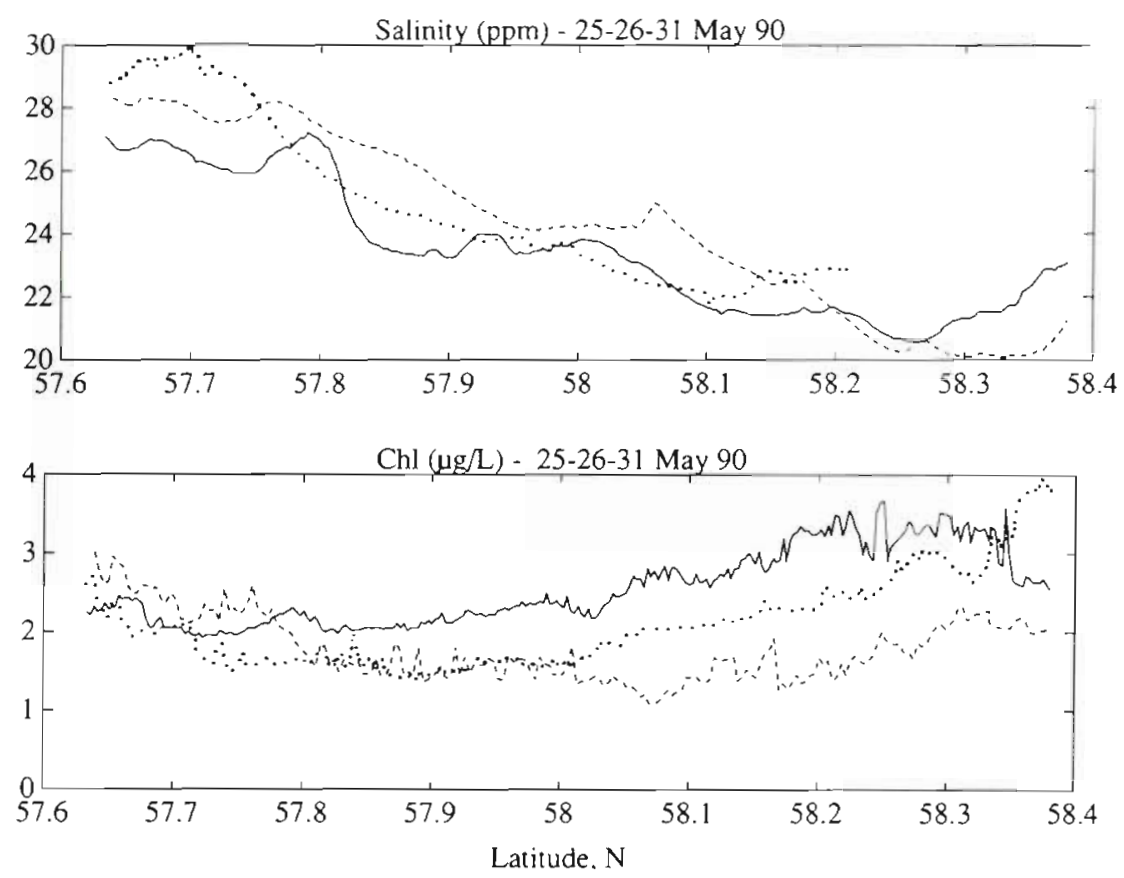

Fig. 3. Variability of near-surface salinity (top) and chlorophyll a (bottom) on consecutive transects of 25 May (continuous line), 26 May (dashed), and 31 May (dotted)
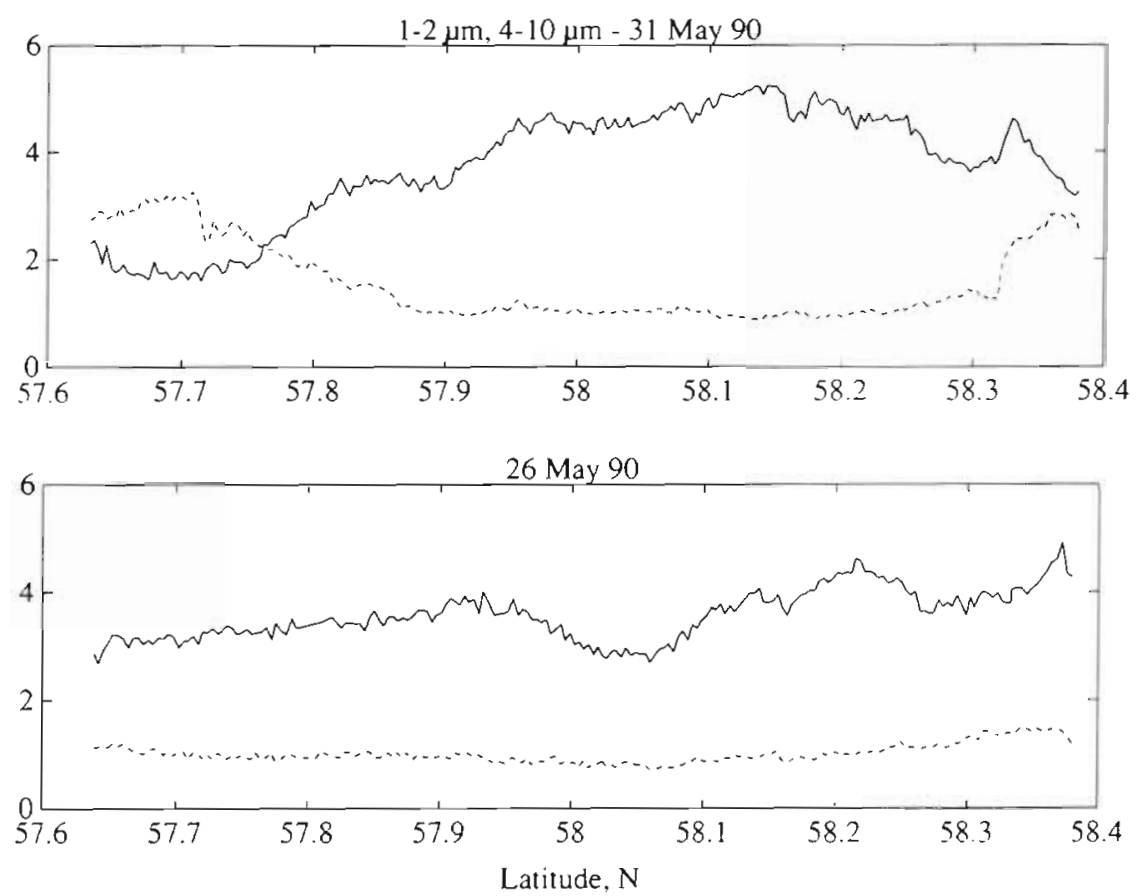

Fig. 4. Concentrations of particles $\left.(\mu)^{-1}\right)$ in size fractions 1-2 $\mathrm{mm}$ (continuous line) and 4-10 $\mu \mathrm{m}$ (dashed) on 31 May (top) and 26 May (bottom)

Counts of the largest particle size fractions occasionally showed erratic spikes (Fig. 7) that occurred predominantly in the 2 coastal areas, and were at least partially caused by agglomerates of chain-forming diatoms breaking loose from the filter in front of the sensor. Spikes in the larger size ranges were also responsible for the small-scale 'jig-saw' variations in the percent estimates of the total particulate surface area in Fig. 5. The spikes on 26 May were clearly associated with the high-salinity water in the Jutland
Current (cf. Fig. 6, top) while, on other transects, similar spiky regions also occurred in the Norwegian Coastal Current.

Correlations between chlorophyll and particle concentrations in the different fractions were not homogeneous over the transect. A visual comparison of the 28-42 $\mu \mathrm{m}$ fraction and chlorophyll distributions (Fig. 6 , bottom) shows that, while on most of the transect of 25 May the distributions corresponded, the correspondence was low or non-existent in certain areas, e.g. on the 
Fig. 5. Percent contributions of the different particle size fractions to the total (1 to $1000 \mu \mathrm{m})$ particulate surface area on 31 May
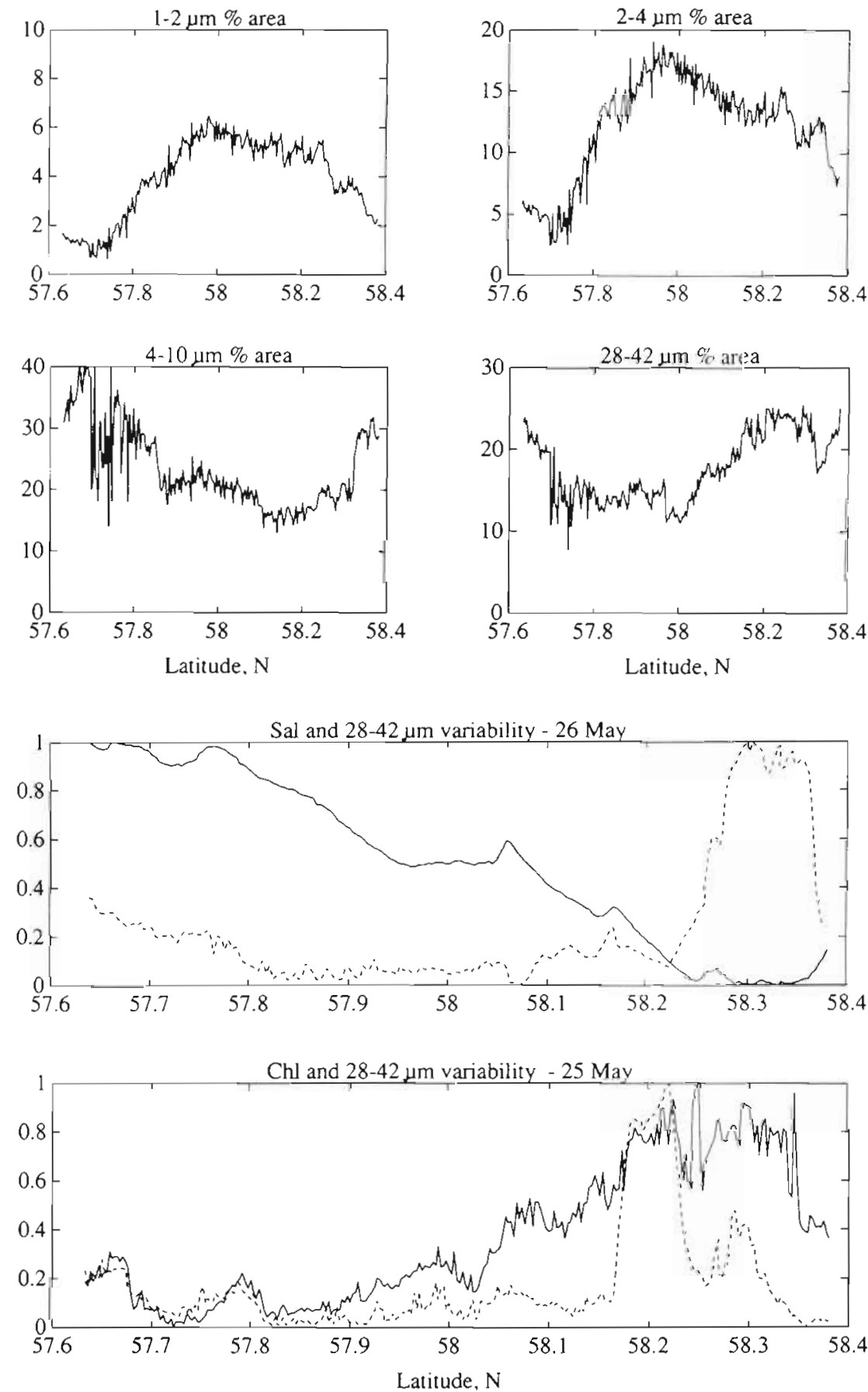

Fig. 6. Normalized (stretched from 0 to 1) distributions of the $28-42 \mu \mathrm{m}$ particle size fraction (dashed line) together with salinity (continuous) (26 May, top) and chlorophyll a (continuous) (25 May, bottom) showing the particle maxima in the low-salinity plumes

northern side of the particle maximum in the lowsalinity plume. Other size fractions conceivably contributed most of the chlorophyll in these areas. Quantitatively, these differences are summarized by the 'running' correlations (Fig. 8, top, dashed line), which show significant correlation on most of the transect and occasional loss of correlation in certain areas, e.g. on the sides of the low-salinity plume. The correlation between chlorophyll and the smallest particle size fractions (Fig.
8, top, continuous line) was negative or insignificant in the coastal currents while occasional highly correlated areas were present in the center. On other transects (Fig. 8 , middle, bottom) the smaller-scale details were different but the general patterns were common. While the 28-42 $\mu \mathrm{m}$ fraction had the highest correlations with chlorophyll in the 2 peripheral areas, the $1-2 \mu \mathrm{m}$ fraction had regions with significant positive correlation in the central area and mostly negative or insignificant corre- 

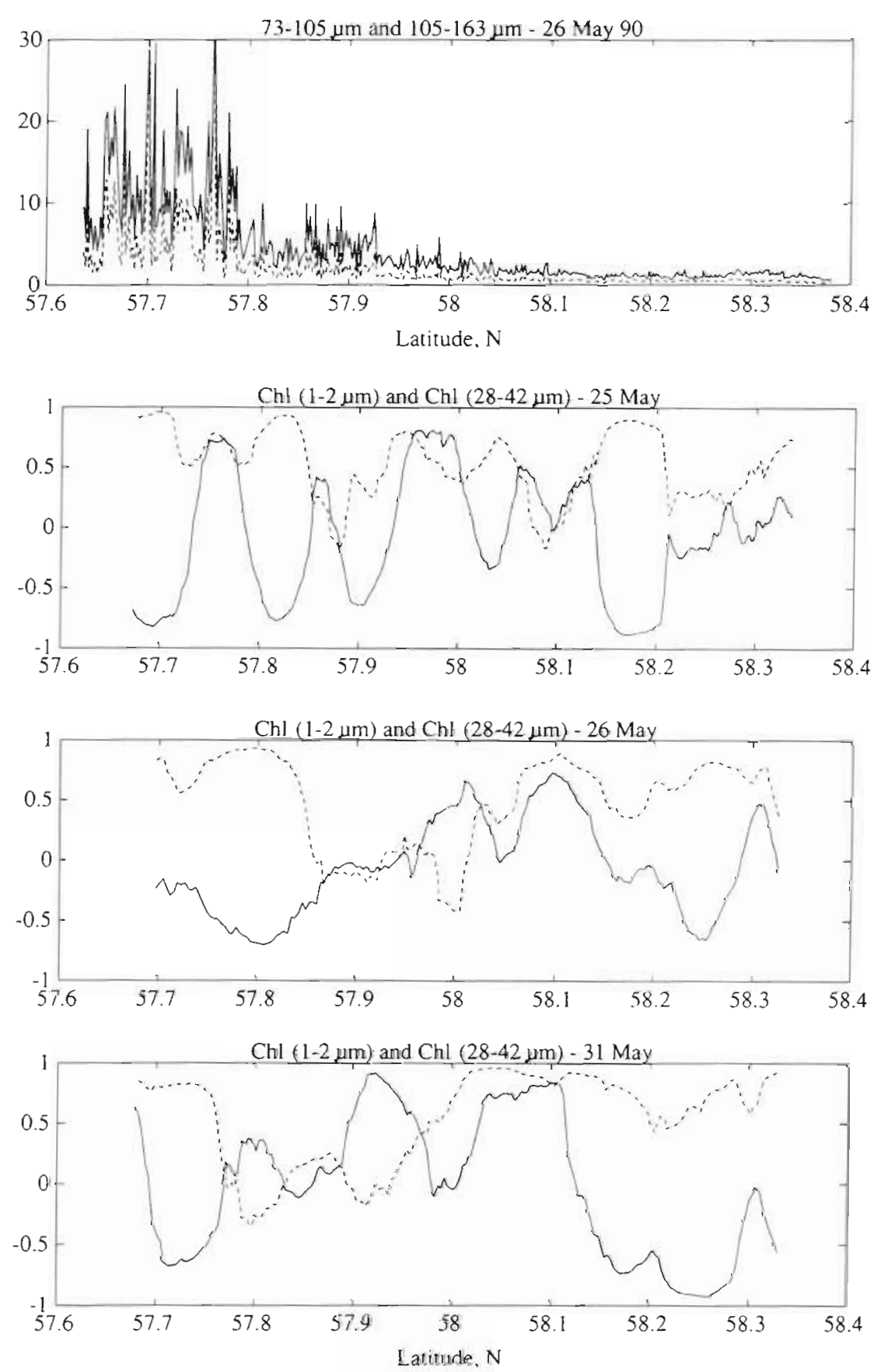

Fig. 7. Concentrations of particles $\left(\mathrm{ml}^{-1}\right)$ in the size fractions of $73-105 \mu \mathrm{m}$ (continuous line) and 105-163 $\mathrm{mm}$ (dashed) on 26 May at spatial resolution ca $250 \mathrm{~m}$
Fig. 8. 'Running' correlation coefficient, $\mathrm{r}$, over 30 adjacent points (ca $15 \mathrm{~km}$ ) between chlorophyll $a$ and, respective. ly, 1-2 $\mu \mathrm{m}$ (continuous line) and 28-42 $\mu \mathrm{m}$ (dashed) particle fractions on 25 May (top), 26 May (middle), and 31 May (bottom) lation on the periphery. Other size fractions (not shown) resembled either the $1-2 \mu \mathrm{m}$ or $28-42 \mu \mathrm{m}$ fraction, with the shift at 4 um.

\section{DISCUSSION}

Although, in a dynamic area like the Skagerrak, the influence of particle resuspension and land runoff is probably not negligible, most of the particles in the measured size range during the biologically productive period are conceivably of biological origin. Indirect proof for the dominance of phytoplankton among the counted particles is provided by the frequently high correlations between certain particle size fractions and chlorophyll, while direct proof has been provided by microscopic examination. Microscopical analysis ( $\mathrm{K}$. Piirsoo pers. comm.) showed that unidentified flagellates were dominant in the phytoplankton and that the diatom Rhizosolenia fragilissima was the most abundant taxon among the 28-73 $\mu \mathrm{m}$ particles. The 1-2 $\mu \mathrm{m}$ and 2-4 um fractions probably represented both auto- 
and heterotrophic nanoflagellates as well as large bacteria. The fraction of the chlorophyll pool contained in cells $<1 \mu \mathrm{m}$, and therefore not accounted for by our particle counter, cannot be estimated.

The spatially highly-resolved measurements across the Skagerrak reveal a variable pattern of particle and chlorophyll distributions, indicating a variable size structure of the planktonic community. The general pattern of the smallest size fraction being more abundant in the central 'dome' area and particles in the diatom size range being clearly dominant in the periphery, which was observed on most of the transects, supports the findings of Kiørboe et al. (1990). In the present study, the 1-4 $\mu \mathrm{m}$ size fraction contributed nearly $25 \%$ of the total particulate surface area of the 1 to $1000 \mu \mathrm{m}$ range in the central Skagerrak (Fig. 5) and was, at least locally, highly correlated with chlorophyll (Fig. 8). While Kiørboe et al. (1990) state that the shift in distribution patterns occurred at $8 \mu \mathrm{m}$, we observed the major shift at $4 \mu \mathrm{m}$. The running correlations calculated between chlorophyll and various particle size fractions showed that, whereas in the periphery the highest correlations were always with the $20-42 \mu \mathrm{m}$ size fractions, in the central parts the correlations with the $1-10$ $\mu \mathrm{m}$ particles were at least locally higher. For the 4-6 $\mu \mathrm{m}$ fraction, the running correlations with chlorophyll were closer to those of the $28-42 \mu \mathrm{m}$ fraction than to those of the 2-4 um fraction. In the Jutland and the Norwegian Coastal currents, the planktonic community was clearly dominated by the larger size fractions, especially by those corresponding to diatom cells and chains.

However, 2 of the 5 transects did not agree with the described general picture. Drastic changes in the horizontal distributions were observed within less than a day. Remotely sensed sea-surface temperature and in situ hydrographic observations provide some clues. It has been observed (Mork 1981, Håkansson 1990) that during southwesterly winds upwelling occurs along the Norwegian coast, and the Norwegian Coastal Current bends southward forming a front between the inner and outer Skagerrak. During approximately the same period in 1989, the location of the front was close to and roughly parallel to our transect (Håkansson 1990). It is evident that small advective movements of the front can cause abrupt changes in the variables measured along the transect making it impossible to infer in situ biological dynamics.

Richardson (1985) has suggested that the intense surface phytoplankton blooms in the Skagerrak area, often causing environmental problems, initially start in the pycnocline. As our measurements were carried out at a single depth, in the surface water, we cannot address this question. However, sharp chlorophyll maxima at about $20 \mathrm{~m}$ depth were present in the pycnocline of the central stations.
The modest increase in chlorophyll a concentration in the low-salinity plumes in the Norwegian Coastal Current, together with the 4 to 5 -fold increase in the concentration of the 28-42 um size fraction (Fig. 6), may indicate declining diatom blooms

It is tempting to conjecture that the different particle size structure in the center of the Skagerrak versus its periphery is indicative of different trophic pathways, supporting the general conclusion of Kiorboe et al. (1990). However, as both the hydrography and the particle concentrations demonstrated abrupt changes, more measurements are needed over a longer period to characterize the ecosystem.

Kiorboe et al. (1990) argue that specific growth rates rather than biomass distributions are preferable to study the response of the biotic community to variations in physical characteristics. This is certainly true. However, in a dynamic and highly variable environment like the Skagerrak, automated, high resolution and fast measurements are needed to match the natural variability. With the exception of some fluorescence measurements, these are not available for most of the physiological processes but high-resolution biomass measurements combined with the rate measurements at selected points could give a more comprehensive understanding of the Skagerrak ecosystem.

Acknowledgements. The whole SKAGEX community deserves credit for stimulating this work. J. Sildam and J. Pavelson helped to transfer and calibrate the thermosalinograph data. Valli Porgasaar kindly provided the extracted chlorophyll values for calibration. Kai Piirsoo allowed the use of her phytoplankton data.

\section{LITERATURE CITED}

Azam, F., Fenchel, T., Field, J. G., Gray, J. S., Meyer-Reil, L. A., Thingstad, F. (1983). The ecological role of water column microbes in the sea. Mar. Ecol. Prog. Ser. 10: 257-263

Cushing, D. H. (1989). A difference in structure between ecosystems in strongly stratified waters and those that are only weakly stratified. J. Plankton Res. 11: 1-13

Fenchel, T. (1974). Intrinsic rate of natural increase: the relationship with body size. Oecologica (Berl.) 14: 317-326

Håkansson, B. (1990). Remotely sensed water mass distributions and large scale sea surface circulations in the Skagerrak. Comm. Meet. Int. Counc. Explor. Sea C.M.-ICES/C:15 Sess. P

Kahru, M., Nômmann, S. (1990). The phytoplankton spring bloom in the Baltic Sea in 1985, 1986: multitude of spatiotemporal scales. Cont. Shelf Res. 10: 329-354

Kahru, M., Nômmann, S., Zeitzschel, B. (1991). Particle (plankton) size structure across the Azores Front (Joint Global Ocean Flux Study North Atlantic Bloom Experiment). J. geophys. Res. C4: 7083-7088

Kiorboe, T., Kaas, H., Kruse, B., Mohlenberg, F., Tiselius, P., Ertebjerg, G. (1990). The structure of the pelagic food web in relation to water column structure in the Skagerrak. Mar. Ecol. Prog. Ser. 59: 19-32

Legendre, L. (1990). The significance of microalgal blooms for 
fisheries and for the export of particulate organic carbon in oceans. J. Plankton Res. 12: 681-699

Legendre, L., Le Fevre, J. (1989). Hydrodynamical singularities as controls of recycled versus export production in oceans. In. Berger, W. H., Smetacek, V S., Wefer, G. (eds.) Productivity of the ocean: present and past. Wiley, Chichester, p. 49-63

Legendre, L., Le Fevre, J. (1990). Merging scales: from individual cells to ecosystems and to global biochemical cycles. NATO/ASI Workshop 'Individual cell and particle analysis in oceanography', Acquafredda di Maratea, Italy, $5 \mathrm{p}$

Malone, T C. (1980). Algal size. In: Morris, 1. (ed.) The physiological ecology of phytoplankton. Blackwell, Oxford, p. 433-463

Mork, M. (1981). Circulation phenomena and frontal dynamics of the Norwegian coastal current. Phil. Trans. R. Soc. A302: 635-647

Pingree, R. D., Holligan, P. M., Mardell, G. T., Harris, R. P.

This article was presented by $T$. Kiorboe, Charlottenlund, Denmark
(1982). Vertical distribution of plankton in the Skagerrak in relation to doming of the seasonal thermocline. Cont. Shelf. Res. 1: 209-219

Platt, T., Denman, K. L. (1978). The structure of pelagic marine ecosystems. Rapp. P.-v. Réun. Cons. int. Explor. Mer 178: $24-27$

Pugh, P. R. (1978). The application of particle counting to an understanding of the small-scale distribution of plankton. In: Steele, J. H. (ed.) Spatial pattern in plankton communities. Plenum, New York, p. 111-129

Richardson, K. (1985). Plankton distribution and activity in the North Sea/Skagerrak-Kattegat frontal area in April 1984 Mar. Ecol. Prog. Ser. 26: 233-244

Sheldon, R. W., Prakash, A., Sutcliffe, W. H., Jr. (1972). The size distribution of particles in the ocean. Limnol Oceanogr 17: 327-340

Svansson, A. (1975). Physical and chemical oceanography of the Skagerrak and the Kattegat. Fish Bd. Sweden, Inst, of Mar. Res. Report No. 1

Manuscript first received: March 12, 1991

Revised manuscript accepted: July 4, 1991 